Pomáhajúce profesie, roč. 4, č. 2, 2021, 5-13

\title{
OŠETROVATEL'SKÉ ČINNOSTI U PACIENTOV S CHEMOTERAPIOU
}

\author{
Zuzana Spáčilová, L'uboslava Pavelová, Alexandra Archalousová \\ Katedra ošetrovatel'stva FSVaZ UKF Nitra \\ zspacilova@ukf.sk, lpavelova2@ukf.sk, aarchalousova@ukf.sk
}

\begin{abstract}
Abstrakt: Ciel': Zistit' významnost' ošetrovatel'ských činností u pacientov s chemoterapiou z klasifikačného systému ošetrovatel'ských intervencií (NIC) Manažment chemoterapie 2240. Metódy: Na zber empirických údajov bola použitá metóda dotazníka, ktorý obsahoval ošetrovatel'ské činnosti z NIC - Manažment chemoterapie 2240 (42 položiek) a identifikačné údaje (10 položiek). Súbor tvorilo 90 sestier - expertiek pracujúcich na onkologických pracoviskách v Slovenskej republike. Výsledky: Zistili sme, že sestry - expertky z NIC - Manažment chemoterapie 2240 označili za významné (hlavné) 15 činností a 27 ošetrovatel'ských činností zaradili medzi menej významné (vedl'ajšie) z celkového počtu 42 ošetrovatel'ských činností. Ani jednu ošetrovatel'skú činnost' neoznačili ako nevýznamnú. Záver: V d'alšom vzdelávaní sestier poukázat' na potrebu venovat' v praxi náležitú pozornost' ošetrovatel'ským činnostiam, ktoré boli v našom výskume označené ako menej významné. Odporúčame spoluprácu s odborníkmi z iných oblastí a s rodinnými príslušníkmi pacienta, aby sa dosiahlo zlepšenie zvládania onkologického ochorenia a jeho dopade na život pacienta a jeho rodiny.
\end{abstract}

Kl'účové slová: Ošetrovatel'ské činnosti. NIC. Chemoterapia. Onkologický pacient.

\section{ÚVOD}

Pod chemoterapiou sa v onkológii rozumie podávanie liekov (cytostatík) s potenciálom zabíjat' bunky (cytotoxickým účinkom). Tieto protinádorové lieky nepôsobia len selektívne na nádorové bunky, ale i na normálne bunky iných tkanív. Cytostatiká, okrem svojho želatel'ného efektu, majú aj vel'a nepriaznivých účinkov na organizmus pacienta. Nepriaznivé účinky chemoterapie delíme na rýchlo nastupujúce reakcie (napr. alergické reakcie, žilové komplikácie, syndróm rýchleho rozpadu nádoru, nauzea, vracanie, nechutenstvo), skoré reakcie po chemoterapii (napr. leukopénia, trombopénia, krvácavé stavy, anémia, stomatitída, faryngitída, esofagitída, enteritída, paralytický ileus, hemoragická cystitída) a neskoré reakcie, dlhodobé následky chemoterapie (napr. kardiopatie, pneumopatie, hepatopatie, pokles sekrécie pohlavných hormónov, aspermia, predčasná menopauza, sekundárne malignity). Sestry, pracujúce s onkologickými pacientmi, musia poznat' nežiaduce účinky chemoterapie kvôli zlepšeniu komfortu pacienta na jednej strane. Na strane druhej aj kvôli tomu, aby vedeli spolu s lekárom poučit' pacienta a jeho rodinu, na čo sa majú pripravit' a ako reagovat' na zmeny zdravotného stavu chorého v domácom prostredí (Schmidtová, 2008; Vorlíček et al., 2012).

Pojem ošetrovatel'ská intervencia nie je označením iba jedného výkonu, ale jedná sa o pomenovanie okruhu starostlivosti, pod ktorý spadá súbor ošetrovatel'ských činností/aktivít potrebných k riešeniu ošetrovatel'ského problému NANDA-I (Jarošová, Sikorová, 2012).

Pred rozhodnutím sa o vol'be ošetrovatel'ských intervencií je dôležitou činnost'ou v rámci ošetrovatel'ského procesu vo fáze posúdenia včasne identifikovat' problémy u pacienta, a stanovit' ošetrovatel'skú diagnózu (Libová, Balková, Jankechová, 2019). V tejto fáze je klúčové objektivizovanie vzniknutých problémov, ošetrovatel'ských diagnóz, tak aby sestra mohla 
efektívne zvolit' vhodné ošetrovatel'ské intervencie (Libová et al., 2018; Libová, Balková, Galbavý, 2020).

Klasifikačný systém ošetrovatel'ských intervencií - NIC (Nursing Interventions Classification) je komplexná štandardizovaná klasifikácia intervencií, ktoré sestry vykonávajú. Obsahuje 514 ošetrovatel'ských intervencií zorganizovaných do 7 domén a 30 tried. Definícia ošetrovatel'skej intervencie Manažment chemoterapie 2240 v klasifikačnom systéme NIC je charakterizovaná ako pomoc pacientovi a jeho rodine pochopit' činnosti a minimalizovat' vedl'ajšie účinky antineoplastických látok. Táto intervencia patrí do domény č. 2 Fyziologické funkcie: komplexné (Physiological: complex), triedy H. Manažment podávania liekov (Drug management) a taktiež je zaradená v doméne č. 3 Behaviorálne (Behavioral), triedy S. Vzdelávanie pacienta (Patient Education). Intervencia má v klasifikácii pridelené číslo 2240 a celkovo obsahuje 42 ošetrovatel'ských činností (Butcher et al., 2018).

Ošetrovatel'ské činnosti sú charakterizované ako konkrétne správanie alebo činnosti, ktoré sestry vykonávajú na dosiahnutie želatel'ných výsledkov pacienta (Butcher et al., 2018). Ako uvádza Krištofová $(2017$, s. 36) „ošetrovatel'ská činnost' je ciel'avedomý, plánovaný a produktívny súbor odborných, špecializovaných, certifikovaných aktivít sestry charakterizovaný myšlienkovou predstavou želatel'ných výsledkov u pacienta/klienta."

Ciel’om výskumu bolo zistit’ významnost' ošetrovatel'ských činností u pacientov s chemoterapiou z klasifikačného systému ošetrovatel'ských intervencií (NIC) - Manažment chemoterapie 2240 (Butcher et al., 2018).

\section{METÓDY}

Na posúdenie významnosti ošetrovatel'ských činností z NIC - Manažment chemoterapie 2240 (Butcher et al., 2018), sme vytvorili hodnotiaci nástroj dotazníkového typu, ktorý obsahoval ošetrovatel'ské činnosti (42 položiek) a identifikačné údaje (10 položiek). Sestry mali za úlohu určit’ pomocou Likertovej škály, ktoré činnosti považujú za najviac významné alebo najmenej významné. Škála obsahovala 5 stupňov, kde 1 = žiadna významnost'; 2 = malá významnost'; $3=$ stredná významnost'; $4=$ vel'ká významnost' a $5=$ najväčšia významnost'. Dotazník taktiež obsahoval nasledovné demografické dáta: pohlavie, súčasná klinická prax (minimálne 1 rok) v oblasti ošetrovatel'ská starostlivost' o pacientov liečených chemoterapiou, diplomová/ rigorózna práca zameraná na danú oblast' (onkologické ošetrovatel'stvo, chemoterapia), publikovaný článok (výskumného alebo teoretického charakteru) v danej oblasti, doktorandská dizertačná práca $\mathrm{v}$ danej oblasti, špecializácia/certifikácia v oblasti klinickej praxe k príslušnej oblasti, vzdelanie, dížka klinickej ošetrovatel'skej praxe, vek a pracovisko sestry.

Po zbere údajov sme pre každú ošetrovatel'skú činnost' vypočítali vážené skóre (VS), ktoré bolo získané súčtom hodnôt priradených každej odpovedi a jeho následným vydelením celkovým počtom odpovedí. K jednotlivým odpovediam boli priradené hodnoty: $5=1 ; 4=0,75 ; 3=0,5 ; 2=$ 0,$25 ; 1=0$. Následne boli jednotlivé činnosti vyhodnotené: činnosti na úrovni viac ako 0,75 boli označené ako významné (hlavné); na úrovni 0,75 - 0,5 ako menej významné (vedl'ajšie) a činnosti pod 0,50 sa, podl'a Fehringa (1987), vyrad'ujú.

Základný súbor tvorili sestry pracujúce na onkologických pracoviskách v Slovenskej republike, kde je pacientom poskytovaná liečba cytostatikami (chemoterapia). Zarad'ujúcimi kritériami boli: pracovná pozícia sestry v zdravotníckom zariadení na onkologickom pracovisku, poskytovanie ošetrovatel'skej starostlivosti pacientom liečených chemoterapiou, súhlas s vyplnením dotazníka, splnenie modifikovaných kritérií pre experta. Zeleníková et al. (2010) zostavili kritériá pre experta v podmienkach Slovenskej a Českej republiky, pričom podl'a modifikovaných Fehringových kritérií sa za experta pokladá sestra, ktorá dosiahne minimálne 4 body. Pôvodný výberový súbor tvorilo 
100 sestier, ale z dôvodu nesplnenia kritérií pre experta bolo zo súboru vyradených 10 sestier. Finálny výberový súbor nakoniec tvorilo 90 sestier - expertiek pracujúcich na onkologických pracoviskách na území Nitrianskeho, Trenčianskeho a Banskobystrického samosprávneho kraja. Celkový priemer veku respondentov bol 44,51 rokov (SD 9,65; min 25; max 64). Priemerná dížka klinickej praxe respondentov bola 19,79 rokov (SD 11,26; $\min 1$; $\max 44$ ).

\section{VÝSLEDKY}

Sestry - expertky hodnotili ošetrovatel'ské činnosti z NIC - Manažment chemoterapie 2240 na základe svojich skúseností. Analýzou odpovedí z dotazníka sme vytvorili tabul'ky a v nich uvádzame akú významnost' (dôležitost') jednotlivým ošetrovatel'ským činnostiam vybraného súboru NIC pripisujú sestry - expertky. Činnosti sme rozdelili na významné (hlavné) a menej významné (vedl'ajšie) (Tabul'ka 1,2). V oboch tabul'kách uvádzame ošetrovatel'ské činnosti v poradí od najvyššej hodnoty VS.

Tabul'ka 1 Ošetrovatel'ské činnosti považované expertmi za najviac významné (hlavné)

\begin{tabular}{|l|c|c|c|}
\hline Ošetrovatel'ská činnost' & SM & VS \\
\hline $\begin{array}{l}\text { Poučit' pacienta, aby okamžite hlásil horúčku, zimnicu, krvácanie z } \\
\text { nosa, nadmerný výskyt podliatin a čiernu dechtovitú stolicu. }\end{array}$ & 4,50 & 0,67 & 0,88 \\
\hline $\begin{array}{l}\text { Dodržiavat' odporúčané pokyny pre bezpečnú manipuláciu } \\
\text { s parenterálnymi antineoplastickými látkami (cytostatikami) } \\
\text { počas ich prípravy a podávania. }\end{array}$ & 4,48 & 0,72 & 0,87 \\
\hline $\begin{array}{l}\text { Poučit' pacienta a rodinu o spôsoboch ako predchádzat' infekcii, } \\
\text { napr. vyhýbanie sa miestam s väčšou koncentráciou l'udí, } \\
\text { používanie vhodných hygienických návykov a správnej techniky } \\
\text { umývania rúk. }\end{array}$ & 4,37 & 0,84 & 0,84 \\
\hline Zaviest' opatrenia proti neutropénii a krvácaniu. & 4,34 & 0,82 & 0,84 \\
\hline Sledovat' možné vedl'ajšie účinky a toxické účinky liečby. & 4,34 & 0,81 & 0,84 \\
\hline $\begin{array}{l}\text { Zabezpečit' dostatočný príjem tekutín na prevenciu dehydratácie a } \\
\text { elektrolytovej nerovnováhy. }\end{array}$ & 4,32 & 0,80 & 0,83 \\
\hline $\begin{array}{l}\text { Podávat' lieky na kontrolu vedl'ajších účinkov (napr. antiemetiká na } \\
\text { nauzeu a vracanie), ak je to potrebné. }\end{array}$ & 4,30 & 0,80 & 0,83 \\
\hline Sledovat' možné príznaky infekcie sliznice ústnej dutiny. & 4,20 & 0,89 & 0,80 \\
\hline $\begin{array}{l}\text { Informovat' pacienta o možnom vypadávaní vlasov, podl'a typu } \\
\text { liečby. }\end{array}$ & 4,16 & 0,89 & 0,79 \\
\hline $\begin{array}{l}\text { Poskytnút' pacientovi konkrétne objektívne informácie týkajúce sa } \\
\text { účinkov liečby, aby sa znížila jeho neistota, strach a úzkost' v } \\
\text { spojitosti s liečbou. }\end{array}$ & 4,13 & 0,90 & 0,78 \\
\hline $\begin{array}{l}\text { Sledovat' účinnost' opatrení zameraných na kontrolu nauzey } \\
\text { a vracania. }\end{array}$ & 4,07 & 0,93 & 0,77 \\
\hline $\begin{array}{l}\text { Zistit' predchádzajúce skúsenosti pacienta s výskytom nauzey a } \\
\text { vracania v súvislosti s chemoterapiou. }\end{array}$ & 4,07 & 0,68 & 0,77 \\
\hline $\begin{array}{l}\text { Podporovat' dobrú ústnu hygienu s použitím pomôcok na čistenie } \\
\text { zubov, ako sú napr. nevoskované, netrhajúce sa zubné nite, sonické } \\
\text { zubné kefky alebo ústne sprchy, ak je to potrebné. }\end{array}$ & 4,06 & 0,96 & 0,76 \\
\hline $\begin{array}{l}\text { Poučit' dlhodobo liečených pacientova ich rodiny o možnosti vzniku } \\
\text { druhých malignít a dôležitosti nahlásenia zvýšenej náchylnosti na } \\
\text { infekciu, únavu alebo krvácanie. }\end{array}$ & 4,03 & 0,95 & 0,76 \\
\hline
\end{tabular}




\begin{tabular}{|l|c|c|c|}
\hline $\begin{array}{l}\text { Umožnit' pacientovi vyjadrenie obáv v súvislosti s prognózou alebo } \\
\text { úspešnost'ou liečby. }\end{array}$ & 4,02 & 0,79 & 0,76 \\
\hline
\end{tabular}

Legenda: AM - aritmetický priemer; SD - smerodajná odchýlka; VS - vážené skóre

Sestry - expertky z NIC - Manažment chemoterapie 2240 označili za významné (hlavné) 15 ošetrovatel'ských činností (t. j. mali hodnotu VS > 0,75) z celkového počtu 42 činností.

Tabul'ka 2 Ošetrovatel'ské činnosti považované expertmi za menej významné (vedl'ajšie)

\begin{tabular}{|c|c|c|c|}
\hline Ošetrovatel'ská činnost' & AM & SD & VS \\
\hline $\begin{array}{l}\text { Uistit' pacienta, že vlasy po ukončení liečby začnú rást', ak je to } \\
\text { potrebné. }\end{array}$ & 4,01 & 0,94 & 0,75 \\
\hline Zhodnotit' nutričný stav a hmotnost'. & 4,00 & 0,89 & 0,75 \\
\hline $\begin{array}{l}\text { Poučit' pacienta a rodinu, aby sa pacient vyhýbal užívania } \\
\text { aspirínových prípravkov. }\end{array}$ & 4,00 & 1,07 & 0,75 \\
\hline $\begin{array}{l}\text { Poučit’ pacienta a rodinu, aby sledovali orgánovú toxicitu, podl'a } \\
\text { typu liečby. }\end{array}$ & 3,96 & 0,85 & 0,74 \\
\hline $\begin{array}{l}\text { Poučit' pacienta o sebaposudzovaní ústnej dutiny, vrátane } \\
\text { subjektívnych a objektívnych príznakov, ktoré má pacient hlásit' } \\
\text { sestre na d'alšie posúdenie (napríklad pálenie, bolest' a citlivost'). }\end{array}$ & 3,89 & 0,85 & 0,72 \\
\hline $\begin{array}{l}\begin{array}{l}\text { Poskytovat' pacientovi a rodine informácie o účinku } \\
\text { antineoplastických látok (cytostatík) na zhubné bunky. }\end{array} \\
\end{array}$ & 3,89 & 1,03 & 0,72 \\
\hline $\begin{array}{l}\text { Poučit' pacienta a rodinu o účinkoch terapie na funkciu kostnej } \\
\text { drene. }\end{array}$ & 3,83 & 1,10 & 0,71 \\
\hline $\begin{array}{l}\begin{array}{l}\text { Podporovat' činnosti zamerané na zmenu identifikovaných } \\
\text { rizikových faktorov. }\end{array} \\
\end{array}$ & 3,78 & 0,97 & 0,69 \\
\hline $\begin{array}{l}\text { Poučit’ pacienta, aby sa vyhýbal extrémnym teplotám a chemickému } \\
\text { ošetreniu vlasov počas liečby. }\end{array}$ & 3,77 & 0,98 & 0,69 \\
\hline $\begin{array}{l}\text { Pomôct' pacientovi pri plánovaní v súvislosti so stratou vlasov, podl’a } \\
\text { potreby, poskytnutím informácií o dostupných alternatívach, ako sú } \\
\text { parochne, šatky, klobúky a turbany. }\end{array}$ & 3,72 & 1,02 & 0,68 \\
\hline Poučit' pacienta, aby sa vyhýbal pikantným a korenistým jedlám. & 3,71 & 0,97 & 0,68 \\
\hline Ponúkat' pacientovi l’ahko strávitel'nú stravu bez výraznej chuti. & 3,69 & 1,03 & 0,67 \\
\hline Poskytovat' výživné, chutné jedlá podl’a výberu pacienta. & 3,64 & 1,07 & 0,66 \\
\hline $\begin{array}{l}\text { Pomôct' pacientovi pri zvládaní únavy plánovaním častých prestávok } \\
\text { na odpočinok, rozvrhnutím aktivít a obmedzením každodenných } \\
\text { požiadaviek, ak je to potrebné. }\end{array}$ & 3,61 & 0,97 & 0,65 \\
\hline $\begin{array}{l}\text { Sledovat' skríningové vyšetrenia pred liečbou u pacientov s rizikom } \\
\text { skoršieho nástupu, dlhšieho trvania a závažnejších vedl'ajších } \\
\text { účinkov. }\end{array}$ & 3,61 & 1,09 & 0,65 \\
\hline Sledovat' závažnost' únavy na základe pacientovho opisu únavy. & 3,56 & 1,06 & 0,64 \\
\hline Minimalizovat' hluk, svetlo a zápach (najmä potravinové pachy). & 3,53 & 1,10 & 0,63 \\
\hline $\begin{array}{l}\text { Poučit' pacienta, aby používal perorálnu suspenziu obsahujúcu } \\
\text { nystatín na kontrolu mykotických infekcií. }\end{array}$ & 3,51 & 1,00 & 0,63 \\
\hline $\begin{array}{l}\text { Poučit' pacienta a rodinu o udržiavaní rovnováhy medzi } \\
\text { energetickým príjmom a výdajom, ak je to potrebné. }\end{array}$ & 3,50 & 0,93 & 0,63 \\
\hline $\begin{array}{l}\text { Poučit' pacienta, že potrebuje častejšie kontroly u stomatológa, } \\
\text { pretože zubný kaz sa môže rýchlo vytvorit'. }\end{array}$ & 3,47 & 0,88 & 0,62 \\
\hline $\begin{array}{l}\text { Iniciovat' činnosti na obnovu zdravia ústnej dutiny, ako je použitie } \\
\text { umelých slín, stimulantov slín, ústnych sprejov bez alkoholu, }\end{array}$ & 3,38 & 1,09 & 0,59 \\
\hline
\end{tabular}




\begin{tabular}{|l|c|c|c|}
\hline $\begin{array}{l}\text { cukríkov bez obsahu cukru a fluoridových prípravkov, ak je to } \\
\text { potrebné. }\end{array}$ & & \\
\hline $\begin{array}{l}\text { Naučit' pacienta relaxačné a odpútavacie techniky, ktoré môže } \\
\text { použit' pred, počas a po liečbe, ak je to potrebné. }\end{array}$ & 3,38 & 1,21 & 0,59 \\
\hline Ponúkat' šest' malých porcií jedla denne, ak sú tolerované. & 3,34 & 1,12 & 0,59 \\
\hline $\begin{array}{l}\text { Podávat' chemoterapeutiká neskoro večer, aby pacient mohol spat' v } \\
\text { čase, ked' sú emetogénne účinky najväčšie. }\end{array}$ & 3,18 & 1,20 & 0,54 \\
\hline $\begin{array}{l}\text { Poučit' pacienta ako si jemne umývat' a česat' vlasy a spat' na vankúši } \\
\text { v hodvábnej obliečke, aby sa zabránilo d'alšiemu vypadávaniu } \\
\text { vlasov, ak je to potrebné. }\end{array}$ & 3,14 & 1,19 & 0,54 \\
\hline $\begin{array}{l}\text { Poučit' pacienta o vplyve terapie na sexuálnu funkciu, vrátane } \\
\text { používania antikoncepcie, ak je to potrebné. }\end{array}$ & 3,11 & 1,24 & 0,53 \\
\hline $\begin{array}{l}\text { Diskutovat' o možných aspektoch sexuálnej dysfunkcie, ak to je } \\
\text { potrebné. }\end{array}$ & 3,07 & 1,24 & 0,52 \\
\hline
\end{tabular}

Legenda: AM - aritmetický priemer; SD - smerodajná odchýlka; VS - vážené skóre

Medzi menej významné (vedl'ajšie) činnosti, t. j. ošetrovatel'ské činnosti z NIC - Manažment chemoterapie 2240, ktoré dosiahli hodnotu VS v rozmedzí 0,5 - 0,75, zaradili expertky 27 ošetrovatel'ských činností z celkového počtu 42 činností. Ani jednu ošetrovatel'skú činnost' neoznačili ako nevýznamnú.

\section{DISKUSIA}

Pri poskytovaní ošetrovatel'skej starostlivosti onkologickým pacientom liečených chemoterapiou, prichádzajú sestry do kontaktu s cytostatikami. Cytostatiká, určené na intravenózne podanie, sa pripravujú bud' centrálne - v lekárni danej nemocnice alebo, ak táto možnost' v nemocnici nie je, sestry riedia cytostatiká $\mathrm{v}$ špeciálne vyhradenom priestore určenom len na tento účel v miestnosti s digestorom. Pri každodennom kontakte s cytostatikami musia sestry dodržiavat' zásady ochrany a bezpečnosti zdravia pri práci, dodržiavat' zásady bezpečnej prípravy cytostatík a správne likvidovat' cytostatický odpad, eliminovat' následky po možnej expozícii kontaktu s cytostatikami a rovnako chránit’ pacienta pred poškodením následkom nesprávnej manipulácie s cytostatikami (Berč, Palková et al., 2008). Ako uvádza Šmídová et al. (2012), štúdie ukázali, že nechránený zdravotnícky personál, ktorý pracoval v prostredí, kde sa podávali cytostatiká, mal v moči vyššiu hladinu mutagénnych látok v porovnaní s pracovníkmi, ktorí s cytostatikami nepracovali. Je teda zrejmé, že ošetrovatel'ský personál bol vystavený pôsobeniu cytostatík, ktoré boli mutagénne. Okrem toho sa u pracovníkov objavili aj iné nežiaduce účinky, napr. zvýšená incidencia potratov, nízka pôrodná váha ich narodených detí, neplodnost'. Ošetrovatel'skú činnost' z NIC - Manažment chemoterapie 2240 - Dodržiavat' odporúčané pokyny pre bezpečnú manipuláciu s parenterálnymi antineoplastickými látkami (cytostatikami) počas ich prípravy a podávania určili z sestry - expertky za významnú (Tab. 1). Podobne aj vo výskume autorky Spáčilovej (2018) považovali pedagógovia a sestry z Českej aj Slovenskej republiky intervenciu Bezpečná manipulácia s chemoterapeutikami jednoznačne za hlavnú.

Myelosupresia (útlm krvotvorby) je najčastejším dôsledkom cytostatickej liečby a tým pádom sú časté aj všetky komplikácie, ktoré s myelosupresiou súvisia, t.j. leukopénia, trombocytopénia, anémia (Vorlíček et al., 2012). Zvlášt' u pacientov s neutropéniou výrazne stúpa riziko infekcie. Práve infekčné komplikácie sú, vedl’a nezvládnutel'ného nádorového ochorenia, druhou najčastejšou príčinou smrti onkologických pacientov (Schmidtová, 2008). V našom výskume sme zistili, že nasledovné ošetrovatel'ské činnosti, majúce vzt’ah k prevencii, resp. zvládnutiu infekcie, sestry označili ako hlavné: poučit’ pacienta a rodinu o spôsoboch ako 
predchádzat' infekcii, napr. vyhýbanie sa miestam s väčšou koncentráciou l'udí, používanie vhodných hygienických návykov a správnej techniky umývania rúk; zaviest' opatrenia proti neutropénii a krvácaniu; sledovat' možné príznaky infekcie sliznice ústnej dutiny; poučit’ dlhodobo liečených pacientov a ich rodiny o možnosti vzniku druhých malignít a dôležitosti nahlásenia zvýšenej náchylnosti na infekciu, únavu alebo krvácanie (Tab. 1).

U väčšiny onkologických pacientov liečených cytostatikami dochádza k narušeniu príjmu potravy. Mnoho z nich trpí nechutenstvom, nauzeou, vracaním, zápchou, hnačkami a poruchami činnosti trávenia. Ako uvádza Spáčilová a kol. (2018), vo výskume realizovanom zo zdravotnej dokumentácie u onkologických pacientov, sestry najčastejšie dokumentovali nasledovné sesterské diagnózy: Nechutenstvo, Riziko nechutenstva, Riziko zvracania, Zvracanie. Nauzea a vracanie významne ovplyvňujú kvalitu života pacienta a vniektorých prípadoch môže pacient kvôli t’ažkostiam odmietat' d'alšiu liečbu nádorového ochorenia. Zo štúdie autorov Yee et al. (2018) vyplynulo, že kým nevol'nost' negatívne postihuje pacienta, tak vracanie t'ažšie prežívali pacientovi najbližší. Autori Clark-Snow et al. (2018) uvádzajú, že podl'a niektorých štúdií nie je dodržiavanie antiemetických odporúčaní optimálne. Onkologické sestry, ako súčast' multidisciplinárneho tímu, môžu pomôct' podporit' vhodnú antiemetickú profylaxiu. $\mathrm{V}$ našom výskume nasledovné ošetrovatel'ské činnosti: podávat' lieky na kontrolu vedl'ajších účinkov (napr. antiemetiká na nauzeu a vracanie), ak je to potrebné; sledovat' účinnost' opatrení zameraných na kontrolu nauzey a vracania; zistit' predchádzajúce skúsenosti pacienta s výskytom nauzey a vracania v súvislosti s chemoterapiou boli zaradené medzi významné (hlavné) (Tab. 1). Podobne aj vo výskume Spáčilovej (2018) hodnotili respondenti intervencie realizované u onkologických pacientov pri skúmaných položkách Nauzea, vracanie, anorexia; Stomatitída, mukozitída; Hnačka, obstipácia ako významné, hlavné. Sestry - expertky, v našom výskume, označili nasledovné ošetrovatel'ské činnosti ako vedl'ajšie (Tab. 2): zhodnotit' nutričný stav a hmotnost'; poučit' pacienta, aby sa vyhýbal pikantným a korenistým jedlám; ponúkat' pacientovi l'ahko strávitel'nú stravu bez výraznej chuti; poskytovat' výživné, chutné jedlá podl'a výberu pacienta; poučit' pacienta a rodinu o udržiavaní rovnováhy medzi energetickým príjmom a výdajom, ak je to potrebné; ponúkat' šest' malých porcií jedla denne, ak sú tolerované; podávat' chemoterapeutiká neskoro večer, aby pacient mohol spat' v čase, ked’ sú emetogénne účinky najväčšie (Tab. 2).

Alopécia (strata vlasov) patrí taktiež medzi časté nežiaduce účinky chemoterapie. V závislosti od druhu a dávky cytostatika sa strata vlasov nemusí týkat' len hlavy. Prejavuje sa aj vypadávaním ochlpenia na tvári (mihalnice, obočie), končatinách, podpazuší a v genitálnej oblasti. Alopécia sa prejavuje 7-10 dní od prvej dávky chemoterapie a vlasy začnú rást' po niekol'kých týždňoch od posledného podania cytostatík (Schmidtová, 2008; Palková, Berč a kol., 2010). Alopécia je psychologicky stresujúci nežiaduci účinok cytostatík. Ako uvádza Trüeb (2010), 47 \% pacientiek považuje vypadávanie vlasov za najviac traumatizujúci aspekt chemoterapie a $8 \%$ pacientiek dokonca redukuje užívanie cytostatík v dôsledku strachu z vypadávania vlasov. Pacientmi je teda alopécia vnímaná negatívne, napriek tomu, že ide reverzibilný nežiaduci účinok chemoterapie. V tejto súvislosti označili sestry z nášho súboru nasledovnú činnost' ako významnú: informovat' pacienta o možnom vypadávaní vlasov, podl'a typu liečby, a tieto činnosti ako menej významné: uistit' pacienta, že vlasy po ukončení liečby začnú rást', ak je to potrebné; poučit' pacienta, aby sa vyhýbal extrémnym teplotám a chemickému ošetreniu vlasov počas liečby; pomôct' pacientovi pri plánovaní v súvislosti so stratou vlasov, podl'a potreby, poskytnutím informácií o dostupných alternatívach, ako sú parochne, šatky, klobúky a turbany; poučit' pacienta ako si jemne umývat' a česat' vlasy a spat' na vankúši v hodvábnej obliečke, aby sa zabránilo d’alšiemu vypadávaniu vlasov, ak je to potrebné (Tab. 2).

Pri poskytovaní ošetrovatel'skej starostlivosti je vel'mi dôležité venovat' rovnaký podiel pozornosti nielen biologickým, ale u onkologických pacientov zvlášt', potrebám psychickým, sociálnym a 
duchovným (Schmidtová, 2008; Libová, Balková, 2017)). Pre psychickú pohodu pacienta je dôležitá i jeho informovanost'. Onkologickí pacienti chcú byt' informovaní a aj využívajú informácie, najmä pri rozhodovaní o liečbe. Edukácia pomáha pacientom zvládnut' vedl'ajšie účinky terapie a zlepšuje dodržiavanie odporúčaní, čo potvrdili autori Chelf et al. (2001) po analýze 176 výskumných článkov venujúcich sa problematike edukácie onkologických pacientov.

V tejto súvislosti sme v našom výskume zistili, že sestry považujú za významné tieto ošetrovatel'ské činnosti: poskytnút' pacientovi konkrétne objektívne informácie týkajúce sa účinkov liečby, aby sa znížila jeho neistota, strach a úzkost' v spojitosti s liečbou a umožnit' pacientovi vyjadrenie obáv v súvislosti s prognózou alebo úspešnost'ou liečby (Tab. 1). Medzi vedl'ajšie činnosti boli zaradené: poskytovat' pacientovi a rodine informácie o účinku antineoplastických látok (cytostatík) na zhubné bunky; poučit' pacienta o vplyve terapie na sexuálnu funkciu, vrátane používania antikoncepcie, ak to je potrebné a diskutovat' o možných aspektoch sexuálnej dysfunkcie, ak to je potrebné (Tab. 2). Z výsledkov prehl'adovej štúdie autorov Koutsopoulou et al. (2010) vyplýva, že onkologické sestry sú schopné poskytnút' kvalitné informácie a v dostatočnom množstve a taktiež pomôct' pacientom interpretovat' informácie poskytnuté inými pracovníkmi. Na druhej strane však viaceré výskumy (Patistea, Siamanta, 1999; Ançel, 2012) naznačujú nesúlad vo vnímaní informačných potrieb pacientov a sestier. Je preto potrebné najskôr presne vyhodnotit' ako pacienti vnímajú svoju potrebu byt' informovaní a na základe identifikácie tejto potreby môže sestra realizovat' edukáciu, ktorá uspokojí danú potrebu. Autor Ançel (2012) považuje za potrebné, aby sa sestry vzdelávali, aby porozumeli vnímaniu a želaniam pacientov, aby mohli poskytovat' individualizované informácie.

\section{ZÁVER}

Z nášho výskumu sme zistili, že sestry - expertky z NIC - Manažment chemoterapie 2240 označili za významné (hlavné) 15 činností a 27 ošetrovatel'ských činností zaradili medzi vedl'ajšie (menej významné) z celkového počtu 42 ošetrovatel'ských činností. Ani jednu ošetrovatel'skú činnost' neoznačili ako nevýznamnú. V súlade $\mathrm{s}$ našimi zisteniami odporúčame, v d'alšom vzdelávaní sestier, uskutočňovanie odborných seminárov, ktoré budú zamerané na ošetrovatel'ské činnosti označené v našom výskume ako menej významné a poukázat' na potrebu venovat' im náležitú pozornost' v praxi. Taktiež odporúčame spoluprácu s odborníkmi z iných oblastí a s rodinnými príslušníkmi pacienta, aby sa dosiahlo zlepšenie zvládania onkologického ochorenia a jeho dopade na život pacienta a jeho rodiny.

\section{LITERATÚRA}

Ançel, G. 2012. Information Needs of Cancer Patients: A Comparison of Nurses' and Patients' Perceptions. In Journal of Cancer Education, 2012, vol. 27, no. 4, p. 631-640. doi: 10.1007/s13187012-0416-2.

Berč, A., Palková, L'. a kol. 2008. Onkologické ošetrovatel'stvo I. [s.l.] : ZZ design studio - Zvonimír Záviš, 2008. 182 s.

Butcher, H. K., Bulechek, G. M., Dochterman, J. M., Wagner, CH. M. 2018. Nursing Interventions Classification (NIC). 7th edition. Elsevier, 2018.512 s.

Clark-Snow, R., Affronti, ML., Rittenberg, CN. 2018. Chemotherapy-induced nausea and vomiting (CINV) and adherence to antiemetic guidelines: results of a survey of oncology nurses. In Support Care Cancer. 2018, vol. 26, no. 2, p. 557-564. doi: 10.1007/s00520-017-3866-6.

Fehring, F. J. 1987. Methods to validate nursing diagnoses. In Heart and Lung the journal of critical care. 1987, vol. 16, no. 6, p. 625-629. 
Chelf, J.H. et al. 2001. Cancer-related patient education: an overview of the last decade of evaluation and research. In Oncol Nurs Forum. 2001, vol. 28, no. 7, p. 1139-47.

Jarošová, D., Sikorová, L. 2012. Ověřování ošetřovatelských intervencí NIC v domáci péči. In Ošetřovatelství a porodní asistence. 2012, roč. 3, č. 1, s. 362-367.

Libová, L., Balková, H. 2017. Ošetrovatel'ské diagnózy vo vybraných chirurgických odboroch. 1. vyd. - Bratislava: Vysoká škola zdravotníctva a sociálnej práce sv. Alžbety, Fakulta zdravotníctva a sociálnej práce sv. Ladislava, Nové Zámky, 2017. - ISBN 978-80-8132-172-6 - 301 s.

Libová, L., Balková, H., Galbavý, D., Bednáriková, M. 2020. Ošetrovatel’stvo v chirurgii - Hodnotiace a meracie nástroje. Martin : Osveta, Martin, 2020. 139 s. ISBN 978-80-8063-491-9.

Libová, L., Balková, H., Jankechová, M. 2019. Ošetřovatelský proces v chirurgii. Praha : Grada, 2019. 162 s. ISBN 978-80-271-2466-4

Libová, L., Solgajová, A., Jankechová, M., Otrubová, J., Balková, H.( 2018). Hodnotiace nástroje a ich využívanie u seniorov. In Zdravotnícke listy. 2018, roč. 6, č. 1, s. 33-39.

Palková, L'., Berč, A. a kol. 2010. Onkologické ošetrovatel'stvo II. [s.l.] : ZZ design studio - Zvonimír Záviš, 2008, 164 s.

Patistea, E., Siamanta, H. 1999. Literature review of patients' compared with nurses' perceptions of caring: Implications for practice and research. In Journal of Professional Nursing, 1999, vol. 15, no. 5, p. 302-312. doi: 10.1016/s8755-7223(99)80056-8.

Koutsopoulou, S., Papathanassoglu E.DE, Katapodi, M.N., Patiraki E.I. 2010. A critical review of the evidence for nurses as information providers to cancer patients. In J Clin Nurs, 2010 vol. 19, no 56, p. 749-785. doi: 10.1111/j.1365-2702.2009.02954.x

Krištofová, E. 2017. Ošetrovatel'ská činnost', aktivita a postup - vymedzenie pojmov v kontexte implementácie ošetrovatel'ských intervencií. In Teoretické vymezení pojmů ve vztahu $k$ implementaci ošetřovatelských intervencí. Recenzovaný sborník vědeckých prací. Ed. A. Archalousová, Plzeň : Západočeská univerzita v Plzni, 2017, s. 31 - 38.

Schmidtová, Z. 2008. Onkologické ošetrovatel'stvo. In Schmidtová, Z. a kol. Vybrané odbory ošetrovatel'stva. Martin : Osveta, 2008, s. 63-104.

Spáčilová, Z. 2018. Validácia špeciálnych onkologických intervencií v onkologickom ošetrovatel'stve. In Poledníková, L., Slamková, A., Spáčilová, Z. 2018. Špeciálne ošetrovatel’ské intervencie $v$ geriatrickom, onkologickom a paliatívnom ošetrovatel'stve. Plzeň: Západočeská Univerzita v Plzni, 2018. s. 53-74.

Spáčilová, Z. a kol. 2018. Ošetrovatel’ská diagnostika v klinickej praxi onkologického ošetrovatel'stva. In Pomáhajúce profesie : recenzovaný vedecký časopis pre teóriu, výskum, prax a vzdelávanie v pomáhajúcich profesiách. 2018, roč. 1, č. 2, s. 39-48.

Šmídová, I., Hadrabová, D., Neumanová, R. 2012. Bezpečnostní a pracovní postupy při práci s cytostatiky. In 17. ročník sympózia Onkologie v gynekologii a mammologii. Dostupné na internete: https://www.linkos.cz/lekar-a-multidisciplinarni-tym/kongresy/po-kongresu/_databazetuzemskych-onkologickych-konferencnich-abstrakt/bezpecnostni-a-pracovni-postupy-pri-pracis-cytostatiky/

Trüeb, R.M. 2010. Chemotherapy-induced hair loss. In Skin Therapy Lett. 2010, vol. 15, no. 7, p. 57.

Vorlíček, J., Abrahámová, J., Vorlíčková, H. et al. 2012. Klinická onkologie pro sestry. Praha: Grada Publishing, 2012. 448 s. 
Yee, C., Drost, L., Zhang, L., Wan, BA., Ganesh, V., Tsao, M., Barnes, E., Pasetka, M., DeAngelis, C., Chow, E. 2018. Impact of radiation-induced nausea and vomiting on quality of life. In Support Care Cancer. 2018, vol. 26, no. 11, p. 3959-3966.

Zeleníková, R., Žiaková, K., Čáp, J., Jarošová, D., Vrublová, Y. 2010. Návrh kritérií výberu expertov pre validizáciu ošetrovatel’ských diagnóz v ČR a SR. In Kontakt, 2010, roč. 12, č. 4, s. 407-413.

\section{NURSING ACTIVITIES IN PATIENTS WITH CHEMOTHERAPY}

Abstract: Objective: To determine the significance of nursing activities from the Nursing Interventions Classification (NIC) - Chemotherapy Management 2240 in patients with chemotherapy. Methods: To collect empirical data, a questionnaire method was used; the questionnaire included nursing activities from the NIC intervention - Chemotherapy Management 2240 (42 items) and identification data (10 items). The sample consisted of 90 expert nurses working in oncology departments in the Slovak Republic. Results: We found out that the expert nurses rated 15 activities as significant (major) and 27 activities as less significant (minor) out of a total of 42 nursing activities from the NIC intervention - Chemotherapy Management 2240. None of the nursing activities was rated as insignificant. Conclusions: In continuing nursing education, in practice it is necessary to emphasise the need to pay due attention to the nursing activities which were rated as minor in the study. We recommend collaborating with experts from other fields and patients' family members to improve cancer management and its impact on the life of patients and their families.

Keywords: Nursing activities. NIC. Chemotherapy. Oncology patient.

Grantová podpora:

Príspevok vznikol za podpory projektu KEGA č. 022 UKF-4/2020 s názvom Implementácia ošetrovatel’ských intervencií do multimediálnych technológií v príprave sestier 2 . 